Отримано: 30 серпня 2018 р.

Прорецензовано: 07 вересня 2018 р.

Прийнято до друку: 13 вересня 2018 р.

e-mail: parasiy_vergunenko@bigmir.net

DOI: 10.25264/2311-5149-2018-10(38)-131-136
Парасій-Вергуненко I. М. Обліково-аналітичне забезпечення стратегічного управління закладами вищої освіти за теорією обмежень. Наукові записки Наиіонального університету «Острозька академія». Серія «Економіка» : науковий журнал. Острог : Вид-во НаУОА, вересень 2018. № 10(38). С. 131-136.

Парасій-Вергуненко Ірина Михайлівна,

доктор економічних наук, професор, професор кафедри обліку в кредитних і бюджетних установах та економічного аналізу ДВНЗ «Київський начіональний економічний університет імені Вадима Гетьмана»

\title{
ОБЛІКОВО-АНАЛІТИЧНЕ ЗАБЕЗПЕЧЕННЯ СТРАТЕГІЧНОГО УПРАВЛІННЯ ЗАКЛАДАМИ ВИЩОЇ ОСВІТИ ЗА ТЕОРІЄЮ ОБМЕЖЕНЬ
}

\begin{abstract}
У статті розглянуто ключові положення теорії обмежень, визначено особливості ї̈ застосування для стратегічного управління закладами вищої освіти, виокремлено основні етапи реалізації цієї теорії. Визначено роль імісие управлінського обліку й аналізу в системі управління $3 B O$ за теорією обмежень. Із метою контролю за обмеженнями та можливістю впливу на них розроблена система аналітичних показників у розрізі двох груп: внутрімніх обмежень потужності (технологічних, кадрових, фінансових) та зовнішніх - ринкових і демографічних обмежень. Запропонована система аналітичних показників має бути покладена в основу побудови управлінських звітів 3 ВО.

Ключові слова: теорія обмежень, управлінський облік, аналіз, заклад вищої освіти, потужність, демографічні обмеження, ринкові обмеження, стратегія.
\end{abstract}

\section{Парасий-Вергуненко Ирина Михайловна,}

доктор экономических наук, профессор, профессор кафедры учета в кредитних и бюджетних организациях и экономического анализа ГВУЗ «Киевский национальный экономический университет имени Вадима Гетьмана»

\section{УЧЕТНО-АНАЛИТИЧЕСКОЕ ОБЕСПЕЧЕНИЕ СТРАТЕГИЧЕСКОГО УПРАВЛЕНИЯ ЗАВЕДЕНИЯМИ ВЫСШЕГО ОБРАЗОВАНИЯ ПО ТЕОРИИ ОГРАНИЧЕНИЙ}

В статье рассмотрены ключевые положения теории ограничений, определены особенности ее применения 8 стратегическом управлении заведениями высшего образования, выделены основные этапы реализации этой теории. Определена роль и место управленческого учета и анализа в системе управления 3 ВО по теории ограничений. С иелью контроля за ограничениями и возможностью влияния на них разработана система аналитических показателей в разрезе двух групп: внутренних - ограничений мощности (технологических, кадровых, финансовых) и внешних - рыночных и демографических ограничений. Предложенная система аналитических показателей может быть положена в основу построения управленческих отчетов $3 B O$.

Ключевые слова: теория ограничений; управленческий учет; анализ, заведение высшего образования, мошность, демографические ограничения, рыночные ограничения, стратегия.

Iryna Parasiy-Vergunenko,

Doctor of Economics, Professor, Professor at the Accounting in Credit and Budgetary Institutions and Economic Analysis Department, Kyiv National Economic University named after Vadym Hetman

\section{ACCOUNTING AND ANALYTICAL SUPPORT TO STRATEGIC MANAGEMENT OF HIGHER EDUCATION ESTABLISHMENTS BASED ON THE THEORY OF CONSTRAINTS}

The article explains the need for reforming the system of the domestic higher education establishments management by applying modern approaches, based on the theory of constraints, to the strategic management. The fundamentals of the theory of constraints are analysed, the special aspects of the theory application in terms of higher education establishments management are defined and the basic implementation steps of the theory are identified. The limiting factors affecting the achievement of strategic goals by business undertakings are defined and comparative analysis of the impact of those factors on the activities of educational establishments is presented. It is demonstrated that the main limiting factors, as applicable to educational establishments, include the following: limited capacities (resources potential), market constraints and demographic constraints. Taking account of the special aspects of educational services, duration period for which is determined by the Law of Ukraine "On Higher Education", it is demonstrated that the time constraints, as applicable to educational establishments (as opposed to business undertakings), do not play a key role in achieving strategic goals. It is proposed to distinguish a separate group of limiting factors, in particular, the "demographic constraints", taking account of which, in terms of educational establishments, allows the management personnel to timely coordinate and revise the development strategy of an establishment.

It is demonstrated that, as applicable to higher education establishments (as opposed to business undertakings, where the key indicator is company profit or company value), the key performance indicators in terms of strategic decisions include the following: increasing competitiveness of the educational establishment by providing high-quality educational services, 
increasing the overall number of students engaged at the higher education establishment, graduate employment rate and professional competence of students acquired at the educational establishment.

The role and functions of management accounting and analysis in the system of management of higher educational establishments, based on the theory of constraints, are defined. In order to control the constraints and the possibilities to affect them, a system of analytical indicators in terms of each group of constraints is proposed. For each group of internal limiting factors of "capacities constraints", the indicators are grouped according to three topics: technological constraints, personnel constraints and financial constraints. The indicators proposed by the author that are used for the analysis of impact of external limiting factors on the results of the activities of educational establishments are grouped under two topics: market constraints and demographic constraints. The proposed system of analytical indicators shall become the basis for drafting management reports by higher education establishments.

Key words: theory of constraints, management accounting, analysis, higher education establishment, capacity, demographic constraints, market constraints, strategy.

Постановка проблеми. Стратегією сталого розвитку «Україна - 2020» [1] та Національною стратегією розвитку освіти в Україні на період до 2021 року [2] передбачено реалізацію низки реформ у сфері освіти, науки та досліджень, трансформацію економічних засад системи освіти, зокрема вдосконалення системи управління закладами вищої освіти як на рівні самого навчального закладу, так і на макрорівні. Вирішення складних, відповідальних і різнопланових завдань щодо якісної підготовки висококваліфікованих фахівців значною мірою залежить від організації управління діяльністю закладів вищої освіти.

Управління сучасним закладом вищої освіти є складним динамічним процесом, який містить постановку стратегічних цілей і завдань, на основі аналізу наявного рівня і стану навчально-виховної та науково-дослідної роботи, раціональної організації творчої діяльності науково-педагогічного складу, пошуку шляхів і засобів удосконалення системи функціонування та розвитку ЗВО, постійного вдосконалення інноваційних і педагогічних технологій. Крім цього, процес управління включає різнопланову роботу 3 обслуговування та забезпечення цих основних напрямів функціонування 3ВО, пошук шляхів ефективного використання матеріально-технічної бази. Посилення конкурентних переваг ЗВО передбачає не просто ефективне використання його ресурсного потенціалу, а й вибір правильної стратегії розвитку 3 урахуванням обмежуючих чинників зовнішнього та внутрішнього середовищ. Із метою налагодження успішного механізму стратегічного управління закладами вищої освіти необхідно організувати системну та цілеспрямовану роботу щодо моніторингу кон'юнктури ринку освітніх послуг, ідентифікації ринкових можливостей, оцінки та результативної протидії різним ризикам.

Докорінна зміна зовнішніх і внутрішніх умов функціонування навчальних закладів у світлі реформ вищої освіти висуває нові вимоги до обліково-аналітичного забезпечення управлінського процесу. В цьому контексті змінюються запити менеджменту щодо інформаційної бази прийняття управлінських рішень, зокрема до системи управлінського обліку й аналізу. Одним із перспективних напрямів удосконалення управлінського процесу в підприємницькому секторі є розвиток управлінського обліку та стратегічного аналізу на основі теорії обмежень (Theory of Constraints) (TOC). Проте вказаний аспект наукових пошуків лише починає привертати увагу вчених і практиків. Якщо в системі управління підприємницького сектора України вже започатковуються засади теорії обмежень (ТОС), то в державному секторі, і зокрема у закладах вищої освіти подібні інструменти практично не використовують. Навіть звичайна система управлінського обліку в навчальних закладах знаходиться на початковій стадії впровадження. Втім, підвищення самостійності ЗВО та посилення конкуренції в освітянському просторі вимагає нових підходів до реформування системи менеджменту та вдосконалення його обліково-аналітичного забезпечення.

Аналіз останніх досліджень і публікацій. Перші наукові праці, присвячені дослідженню впливу обмежень на управління витратами компаній належали ізраїльському фізику Ельяху Голдрату, який став засновником нової революційної концепції управління - теорії обмежень [3; 4; 5]. Надалі ідеї теорії Е. Голдрата були підтримані і розвинуті у працях зарубіжних учених Д. Галловея [6], У. Норина [7], Д. Сміта [7], Т. Маккея [7], Т. Корбетта [8], які запропонували новий підхід до аналізу витрат, що грунтується на обліку пропускної здатності системи (Throughput). Останнім часом концепція трансформації підходів до побудови управлінського обліку на основі теорії обмежень стала об'єктом уваги вітчизняної наукової спільноти, зокрема, цьому питанню присвячено наукові праці вчених, серед яких: О. Андросенко [9], С. Голов [10], В. Козак [11] Н. Михайлишин [12] Н. Стеблюк [13] та ін. Практично всі праці зазначених науковців описують механізм використання теорії обмежень в управлінській та обліковій практиці суб'єктів господарювання різних видів діяльності. Проте проблеми впровадження революційної концепції теорії обмежень у систему управління підприємств державного сектору та його обліково-аналітичне забезпечення поки ще залишається поза зоною уваги науковців.

Метою статті $є$ розроблення теоретичних засад обліково-аналітичного забезпечення стратегічного управління закладів вищої освіти на основі теорії обмежень, визначення основних особливостей ії впровадження та розроблення системи аналітичних показників для контролю й управління внутрішніми, а також зовнішніми обмеженнями. 
Виклад основного матеріалу. Впровадження системи управління на основі теорії обмежень у практику закладів вищої освіти передбачає, що їх розглядають як специфічні освітні корпорації, які мають ознаки ринкового суб“єкта й одночасно є інституціями, що продукують суспільні блага. Подвійний статус навчальних закладів зумовлює необхідність вирішення нових завдань, які будуть відрізнятись від завдань інших суб'єктів господарювання. Якщо для більшості суб’єктів господарювання основною ціллю їхнього функціонування є отримання прибутку, збільшення чистого грошового потоку, зростання вартості компанії, то для державних закладів вищої освіти, які за своїм статусом поки залишаються бюджетними установами (в перспективі набудуть статусу неприбуткових організацій), основною ціллю є підвищення їх конкурентоспроможності через надання якісних освітніх послуг, а значить отримання прибутку не передбачається. Водночас для приватних навчальних закладів поряд із вище зазначеними завданнями отримання прибутку залишається пріоритетною ціллю.

Специфіка освітнього процесу має певні особливості реалізації своїх програмних цілей, що зумовлює необхідність адаптації до них сучасних механізмів менеджменту, зокрема управління за теорією обмежень (Theory of Constraints - TOC). Згідно з цією теорією будь-яку компанію розглядають як систему, що складається із сукупності взаємопов'язаних елементів, дія яких обмежена певними факторами. Для успішної реалізації цілей компанії необхідно врахувати найбільш суттєві лімітуючі фактори (обмеження), які перешкоджають їх досягненню. Водночас стратегічні цілі можуть постійно корегуватися 3 метою нейтралізації впливу таких факторів.

Алгоритм практичного використання ТОС складається з п’яти послідовних етапів (кроків) (рис.1).

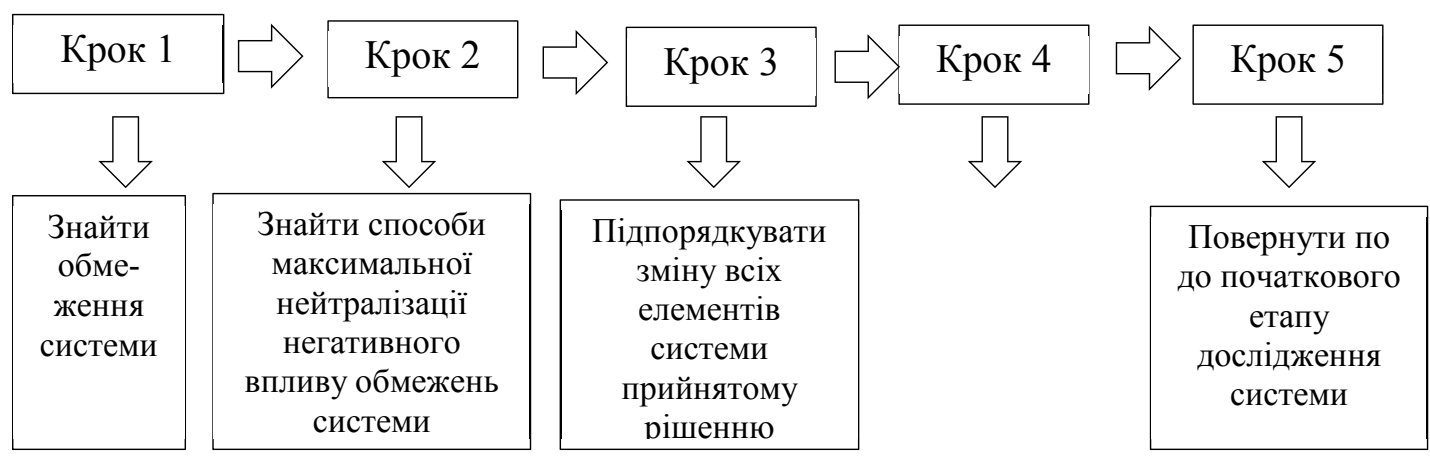

Рис. 1. Етапи практичного використання теорії обмежень (TOC)

Складено автором за [5, с. 82; 6, с. 63-64].

На першому етапі знаходять усі обмеження системи (внутрішні та зовнішні). Зазвичай обираються ті обмеження, які підприємство може нейтралізувати, насамперед, або використати 3 максимальною користю для досягнення поставлених цілей. Уважають, що на підприємстві завжди є певний ресурс, що обмежує досягнення стратегічних цілей. Тобто поліпшення результатів роботи системи починається 3 пошуку найслабкішої ланки, покращення якої здійснюється через мобілізацію внутрішніх резервів компанії. На другому етапі розробляються заходи з нейтралізації дії обмежуючих факторів, на які компанія може вплинути, або використати їх дію з вигодою для компанії. На третьому етапі управлінські дії мають спрямовуватися на підпорядкування роботи всієї компанії (всіх інших ланок) ключовим цілям із метою виконання заходів із мобілізації внутрішніх ресурсів по нейтралізації обмежуючих факторів, що були розроблені на другому етапі. На четвертому етапі розробляються заходи щодо «розширення обмежень» системи через збільшення потужності, скорочення операційного циклу, виробництво нових видів продукції, вихід на нові ринки. П'ятий етап замикає коло пошуку варіантів поліпшення роботи системи на основі управління обмеженнями. За необхідності продовжити роботу з удосконалення управління обмеженнями управлінці повертаються до першого кроку і повторюють всі етапи з урахуванням нових змін системи, отриманих на попередній стадії.

Обмеження можуть бути внутрішні та зовнішні. Внутрішні обмеження пов'язані з недостатністю певного ресурсу в самій компанії, зовнішні - пов'язані з умовами зовнішнього середовища, які менше піддають контролю та корегуванню з боку господарюючих суб'єктів. Зазвичай, у теорії обмежень виокремлюють три їх види: обмеження потужності, обмеження ринку й обмеження часу. Слід зазначити, що впровадження системи управління закладами вищої освіти на основі теорії обмежень має свої особливості, пов'язані зі специфікою продукування (надання) освітніх послуг та іншими (ніж у суб'єктів господарювання) цілями діяльності. Порівняльну характеристику видів обмежень, що притаманні підприємствам підприємницького сектору та закладам вищої освіти, наведено в таблиці 1. 
Види обмежень в діяльності суб'сктів господарювання та закладів вищої освіти за ТОС

\begin{tabular}{|c|c|c|}
\hline $\begin{array}{l}\text { Види обме- } \\
\text { жень }\end{array}$ & $\begin{array}{l}\text { Характеристика обмежень і його на- } \\
\text { слідки для суб’сктів господарювання }\end{array}$ & $\begin{array}{c}\text { Характеристика обмежень і його наслідки } \\
\text { для закладів вищої освіти }\end{array}$ \\
\hline $\begin{array}{l}\text { Обмеження } \\
\text { потужності } \\
\text { (внутрішні) }\end{array}$ & $\begin{array}{l}\text { Означає, що попит на продукцію компа- } \\
\text { нії обмежується можливостями матері- } \\
\text { ально-технічної бази. }\end{array}$ & $\begin{array}{l}\text { Означає, що попит на кваліфікованих спеціалістів вище, } \\
\text { ніж можливості навчальних закладів з їх підготовки. Вони } \\
\text { пов’язані з обмеженням бюджетного фінансування, недо- } \\
\text { статністю аудиторного фонду, недостатньою забезпеченістю } \\
\text { кадрами та їх кваліфікацією, наявністю ліцензій тощо. }\end{array}$ \\
\hline $\begin{array}{l}\text { Обмежен- } \\
\text { ня ринку } \\
\text { (зовнішні) }\end{array}$ & $\begin{array}{l}\text { Означає, що попит на продукцію нижче, } \\
\text { ніж може виробити компанія, або реалі- } \\
\text { зація продукції обмежується конкурен- } \\
\text { цією на відповідних сегментах ринку. }\end{array}$ & $\begin{array}{l}\text { Означає, що попит на фахівців незбалансований відповід- } \\
\text { но до випуску навчальними закладами спеціалістів певних } \\
\text { спеціальностей, що відбивається на їх працевлаштуванні. } \\
\text { Ринкові обмеженні пов’язані також з конкуренцією на осві- } \\
\text { тянському ринку, платоспроможністю населення, запитами } \\
\text { потенційних абітурієнтів щодо якості освітніх послуг ЗВО. }\end{array}$ \\
\hline $\begin{array}{l}\text { Обмеження } \\
\text { часу } \\
\text { (внутрішні) }\end{array}$ & $\begin{array}{l}\text { Означає, що час на виробництво продук- } \\
\text { ції, виконання замовлення, реалізацію } \\
\text { проекту або отримання іншого результа- } \\
\text { ту в компанії більше, ніж у конкурентів. }\end{array}$ & $\begin{array}{l}\text { В освітній діяльності дане обмеження не відіграє ключової } \\
\text { ролі, оскільки підготовка закладами вищої освіти фахівців } \\
\text { регламентована стандартами вищої освіти, технологія на- } \\
\text { дання освітньої послуги передбачає певну їі тривалість і не } \\
\text { передбачає прискорення процесу. }\end{array}$ \\
\hline $\begin{array}{l}\text { Демографічні } \\
\text { обмеження } \\
\text { (зовнішні) }\end{array}$ & - & $\begin{array}{l}\text { Для закладів вищої освіти демографічні обмеження суттєво } \\
\text { впливають на масштаби їх діяльності, які залежать кількості } \\
\text { випускників середніх навчальних закладів і часткою пре- } \\
\text { тендентів на отримання вищої освіти. }\end{array}$ \\
\hline
\end{tabular}

*Розроблено автором.

Обмеження потужності закладів вищої освіти належать до внутрішніх чинників, що стримують їх розвиток, проте вони краще піддаються управлінню, ніж зовнішні. Такий чинник має місце в умовах низької конкуренції на освітянському ринку, коли ринок праці здатний прийняти фахівців із вищою освітою, а ЗВО не в змозі задовольнити його запити. Фактично, такі обмеження пов'язані з недостатністю бюджетного фінансування, низьким рівнем ресурсного потенціалу навчального закладу, до яких зазвичай відносять обмеженість аудиторного фонду навчального закладу, гуртожитків, наявність ліцензій на проведення освітніх послуг, недостатність висококваліфікованих викладачів, які забезпечують підготовку фахівців певних спеціальностей. Для закладів освіти приватної форми власності такі внутрішні обмеження пов'язані з недостатністю власних фінансових ресурсів, спрямованих на фінансування освітнього процесу.

Якісна складова обмежень групи (ресурсних обмежень) для навчальних закладів може бути зумовлена недостатньою кваліфікацією викладацького персоналу, низьким рівнем їх фахових компетенцій, недосконалістю освітніх програм і навчальних планів (неврахування запитів ринку праці щодо загальних і фахових компетентностей випускників 3ВО), неможливістю надання якісного навчального продукту внаслідок слабкої інноваційної складової та технічної бази навчального закладу (брак або недостатність програмних продуктів, технічних засобів навчання, сучасних лабораторій, навчальних центрів).

Ринкові обмеження діяльності ЗВО належать до зовнішніх чинників, процес управління якими більш складний і потребує грунтовних наукових досліджень потреб ринку та тенденцій його розвитку. О. Коуен і Ф. Федірко вважають, що «обмеження ринку є стратегічним обмеженням компанії, оскільки саме ринок забезпечує компанії зростання. У певних випадках можна вибрати потужність або час виконання як вторинне обмеження на перехідному етапі» [14, с. 44].

Вказана група обмежень пов’язана з наявністю конкуренції на освітянському ринку, яка залежить від загальної кількості навчальних закладів, їх конкурентоспроможності, ефективності цінової політики, якості та конкурентоспроможності освітніх послуг кожного конкретного закладу. Неврахування сучасних тенденцій та інфраструктури вітчизняної економіки призводить до незбалансованості запитів ринку праці та кількості спеціалістів відповідного фаху, які випускають ЗВО. Нехтування подібними ринковими обмеженнями закладами вищої освіти мають негативні наслідки, які гостро проявились у сучасних умовах, коли спостерігається надлишок таких фахівців як бухгалтера, юристи, фінансисти, банківські фахівці. Результати вступних компаній останніх років проілюстрували недосконалість менеджменту закладів вищої освіти, і зокрема неврахування ринкових обмежень під час планування напрямів підготовки спеціалістів.

Специфіка надання освітніх послуг накладає певні особливості використання такого обмежувального чинника як «обмеження часу». Якщо для суб'єктів господарювання підприємницького сектору такий обмежувальний фактор є ключовим показником ефективності управління, від якого залежить швидкість отримання результату діяльності (тобто в одиницю часу продукується більший обсяг прибутку, або маржинального доходу), то для закладів вищої освіти він практично не діє, оскільки на свій розсуд вони не можуть прискорити тривалість підготовки спеціалістів. Зокрема, згідно зі ст. 5 Закону «про вищу освіту» 
обсяг освітньо-професійної підготовки бакалавра складає 180-240 кредитів ЄКТС (по 30 годин), а підготовки магістрів - 90-120 кредитів СКТС, за винятком медичних, фармацевтичних, ветеринарних університетів, для яких тривалість підготовки магістрів збільшена до 300-360 кредитів ЄКТС [15].

Якщо для суб'єктів господарювання демографічні обмеження, зазвичай не беруть до уваги в теорії обмежень, то для закладів вищої освіти такий лімітуючий фактор відіграє ключову роль у системі заходів підтримки їх життєздатності, особливо в період «демографічної ями». Зрозуміло, що на цей фактор безпосереднього впливу заклади освіти не мають, проте під час розроблення кадрової та цінової політики не враховувати демографічні обмеження неможливо.

Таблиия 2

Система аналітичних показників для управління та закладами вищої освіти за теорією обмежень

\begin{tabular}{|c|c|c|}
\hline $\begin{array}{l}\text { Види } \\
\text { обме- } \\
\text { жень } \\
\end{array}$ & $\begin{array}{l}\text { Тематичні } \\
\text { блоки }\end{array}$ & Аналітичні показники \\
\hline \multirow{3}{*}{ 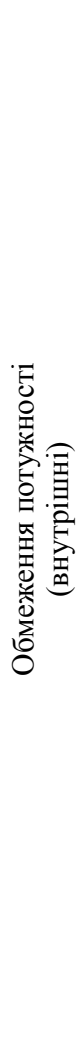 } & $\begin{array}{c}\text { Технологічні } \\
\text { та технічні } \\
\text { обмеження }\end{array}$ & $\begin{array}{l}\text { Коефіцієнт використання аудиторного фонду. } \\
\text { Частка навчальних площ із загальній площі ЗВО, \%. } \\
\text { Коефіцієнт змінності використання аудиторного фонду. } \\
\text { Забезпеченість наівчальних аудиторій мультимедійним обладнанням, \% (норматив } \geq 30 \%) \text {. } \\
\text { Кількість площ навчальних приміщень у розрахунку на одного студента, }{ }^{2}\left(\text { норматив } \geq 2,4 \text { м²). }^{2} \text {. }\right. \\
\text { Рівень забезпеченості студентів гуртожитками, \% (норматив } \geq 70 \%) . \\
\text { Ліцензійний обсяг за окремими спеціальностями та в цілому по ЗВО. }\end{array}$ \\
\hline & $\begin{array}{c}\text { Кадрові об- } \\
\text { меження }\end{array}$ & $\begin{array}{l}\text { Співвідношення кількості викладачів, що мають наукові ступені (зокрема, кандидатів і докто- } \\
\text { рів наук) до загальної кількості науково-педагогічних працівників, \%. } \\
\text { Частка науково-педагогічних працівників в загальній чисельності персоналу 3ВО, \%. } \\
\text { Частка викладачів, які мають науковий ступінь (або вчене звання), що здійснюють підготовку } \\
\text { бакалаврів (норматив } \geq 50 \%) \text {. } \\
\text { Частка викладачів, що мають науковий ступінь (або вчене звання), що здійснюють підготовку } \\
\text { магістрів (норматив } \geq 60 \%) . \\
\text { Частка викладачів, які мають науковий ступінь доктора наук (або вчене звання професора), що } \\
\text { здійснюють підготовку бакалаврів (норматив } \geq 10 \%) \text {. } \\
\text { Частка викладачів, які мають науковий ступінь доктора наук (або вчене звання професора), що } \\
\text { здійснюють підготовку магістрів (норматив } \geq 50 \%) . \\
\text { Кількість публікацій у фахових виданнях у розрахунку на одного науково-педагогічного працівника; } \\
\text { Кількість патентів (авторських свідоцтв) у розрахунку на одного науково-педагогічного пра- } \\
\text { цівника. }\end{array}$ \\
\hline & $\begin{array}{l}\text { Фінансові } \\
\text { обмеження }\end{array}$ & $\begin{array}{l}\text { Співвідношення витрат на оплату праці науково-педагогічного персоналу та іншого персоналу } \\
\text { (спеціалістів, робітників, адміністративного й обслуговувального персоналу). } \\
\text { Частка бюджетних місць у загальній кількості здобувачів освіти. } \\
\text { Середні витрати в розрізі спеціальностей на підготовку одного бакалавра, магістра, аспіранта, } \\
\text { докторанта (в конкретному ЗВО та в інших закладах). } \\
\text { Вартість навчання (за контрактом) одного бакалавра, магістра, аспіранта, докторанта за спеці- } \\
\text { альностями. } \\
\text { Співвідношення витрат за загальним та спеціальним фондом. }\end{array}$ \\
\hline \multirow{2}{*}{ 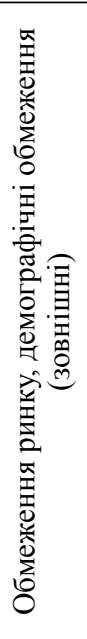 } & $\begin{array}{c}\text { Ринкові об- } \\
\text { меження }\end{array}$ & $\begin{array}{l}\text { Загальна кількість 3ВО, що функціонують на освітянському ринку (в т. ч. державних). } \\
\text { Рівень конкуренції на освітянському ринку. } \\
\text { Середня частка ринку закладу вищої освіти. } \\
\text { Відносна частка ринку ЗВО (відношення частки ринку ЗВО до середньої частки ринку). } \\
\text { Співвідношення вартості навчання в ЗВО та середньою вартістю навчання в країні за окреми- } \\
\text { ми спеціальностями. } \\
\text { Загальна кількість студентів, що навчаються в ЗВО. } \\
\text { Рейтинг ЗВО за кількістю студентів, що навчаються. } \\
\text { Кількість ЗВО, що здійснюють підготовку фахівців певної спеціальності. }\end{array}$ \\
\hline & $\begin{array}{l}\text { Демогра- } \\
\text { фічні об- } \\
\text { меження }\end{array}$ & $\begin{array}{l}\text { Рівень заповнюваності ліцензійного обсягу, \%. } \\
\text { Процент заповнюваності бюджетних місць абітурієнтами. } \\
\text { Динаміка кількості абітурієнтів, які вступили до ЗВО в цілому та окремими спеціальностями. } \\
\text { Загальна кількість випускників шкіл у поточному році та в перспективній динаміці. } \\
\text { Коефіцієнт розширення (скорочення) студентського контингенту, порівняно з попереднім } \\
\text { роком. } \\
\text { Частка абітурієнтів, що вступили до закладу вищої освіти, в загальній кількості випускників } \\
\text { шкіл (в поточному та попередньому роках). } \\
\text { Рівень народжуваності в країні (в поточному періоді та перспективному). } \\
\end{array}$ \\
\hline
\end{tabular}

*Розроблено автором.

В основі обліково-аналітичного забезпечення управління закладами вищої освіти лежить система кількісних і якісних вимірів, тобто система аналітичних показників, на базі яких здійснюють контроль за досягненням стратегічних цілей компанії. Якщо для підприємницьких структур основним ключовим 
показником ефективності діяльності є отримання прибутку (або збільшення вартості компанії), то для закладів вищої освіти ключовими показниками результативності роботи $є$ підвищення конкурентоспроможності навчального закладу через надання якісних освітніх послуг, збільшення загального обсягу студентів, що навчаються у ЗВО, рівень працевлаштування випускників, ступінь оволодіння студентами професійними компетенціями, що надаються в навчальному закладі тощо.

Контроль за обмеженнями в закладах вищої освіти та розроблення відповідних заходів із мінімізації ïx негативного впливу має здійснюватись також на основі аналітичних показників. Водночас інформація про внутрішні обмеження має знайти своє відображення в управлінському обліку та аналітичних звітах навчальних закладів, а інформація про зовнішні обмеження (ринкові обмеження, демографічні обмеження) може бути отримана тільки на основі зовнішніх джерел інформації (статистичних щорічників, маркетингових досліджень ринку, даних рейтингових агенцій, інформаційних бюлетенів тощо).

Для цілей управління на основі теорії обмежень пропонуємо систему аналітичних показників, які дають змогу контролювати можливості вищих навчальних закладів з урахуванням внутрішніх та зовнішніх обмежень та розробляти відповідні заходи щодо мінімізації їх впливу (таблиця 2).

Запропоновані показники, дають змогу кількісно виміряти ризики і загрози для розвитку ЗВО з урахуванням впливу обмежуючих факторів. Порівняння відповідних показників з показниками інших навчальних закладів дає змогу провести SWO-аналіз, на основі якого визначаються слабкі та сильні сторони ЗВО, визначити обмежуючі фактори, що стримують його розвиток, розробити заходи щодо усунення такого впливу та проводити контроль за їх виконанням.

Висновки. Отже, реалізація реформ в освітній сфері, спрямованих на підвищення якості освітніх послуг та посилення конкурентних переваг вітчизняних навчальних закладів неможлива без модернізації процесу управління ними. Одним із перспективних напрямів удосконалення управління навчальними закладами $є$ використання теорії обмежень, яка дає змогу знайти їх слабкі місця, визначити фактори, що негативно впливають на їх розвиток, винайти резерви покращення освітньої діяльності, пов'язані з неповним використанням його ресурсного потенціалу, або розробити заходи з його покращення.

Використання теорії обмежень в управлінні закладами вищої освіти висуває нові вимоги до інформаційного забезпечення цим процесом, i, насамперед, до управлінського обліку й економічного аналізу. Запропонована система аналітичних показників має бути покладена в основу побудови управлінських звітів закладів вищої освіти.

\section{Література:}

1. Указ Президента України «Про стратегію сталого розвитку «Україна-2020». URL: http:// zakon2.rada. gov. ua/laws/show/5/2015.

2. Указ Президента України «Про національну стратегію розвитку освіти в Україні на період до 2021 року». URL: http://zakon2.rada.gov.ua/laws/ show/344/2013.

3. Goldratt E. M. Cost Accounting: The number One Enemy of Productivity / International Conference Proceeding's, American Production and Inventory Control Society. 1983. - 446 p.

4. Goldratt E. M. From Cost World to Throughput World. Advances in Management Accounting. 1992. P. 35-53.

5. Голдрат Э. М., Конс Дж. Цель: процесс непрерывного совершенствования; пер с англ. П. А. Самсонова. Мн.: ООО «Попурри», 2004. 560 с.

6. Galloway D., Waldron D. Throughput Accounting - 1: The need for a new language for manufacturing . Management Accounting . 1988. November. P. 34-35.

7. Noreen E., Smith D., Mackey T. J. The Theory of Constraints and Implications for Management Accounting. North River Press, 1995. 216 p.

8. Корбетт Т. Управлінський облік за ТОС / пер. С англ. Д. Капранов. К.: видавництво «Необхідно і достатньо», 2009. $240 \mathrm{c}$.

9. Андросенко О. О. Бухгалтерський облік і аналіз в управлінні витратами: автореф. дис.... канд. екон. наук: 08.00.09. Київ, 2015. 21 с.

10. Голов С. Ф. Управлінський облік на основі теорії обмежень. Бухгалтерський облік і аудит. 2012. № 6. C. $40-48$.

11. Козак В. С. управлінський облік за теорією обмежень: загальна характеристика. Вісник Хмельнищького наиіонального університету. 2009. № 6. С. 170-174.

12. Михайлишин Н. П., Мельник Н. Г. ТОС - теорія, що ламає стереотипи. Сталий розвиток економіки. 2011. № 4. C. 81-83.

13. Стеблюк Н. Ф., Волосова Н. М. Прийняття управлінських рішень засобами теорії обмежень системи і нечіткої логіки в системі стратегічного управління. Економічний вісник Запорізької держсавної академії. 2016. № 3(03). С. 62-65.

14. Коуен О., Федурко О. Основи теорії обмежень. Талін: ТОС Strategic Solutions. 2012. 331 c.

15. Закон України «Про вищу освіту» від 01.07.2014 № 1556-VII. URL: http://zakon4.rada.gov.ua/laws/ show/1556-18/page. 